\title{
A Glimpse of Poverty and Nutritional Status and their Impact on The Namibian Child
}

\author{
Fred J Mwilima* \\ University of Namibia, Namibia
}

Submission: October 24, 2018; Published: November 19, 2018

*Corresponding author: Fred J. Mwilima, University of Namibia, Namibia

Abstract

This paper will examine the effect of poverty on the nutritional state of the Namibian child. Namibia is a country with a population of 2.3 million people which is growing at a rate of 2.6 percent per annum [1] (NSA, 2016). The country gained independence in 1990 after nearly a century of German and South African rule and is classified a lower middle-income country [2] (UNDP, 2018). Two documents are catalytic in providing a general view of Namibia's nutritional status; the Food and Nutrition Guidelines for Namibia and Food and Nutrition Policy for Namibia and The Nutrition Country Profile, a research conducted by Food and Agricultural Organisation (FAO). In Namibia, there is a widespread of undernutrition among children less than five years of age, a chronic rate of unemployment standing at 28.7 and 15.3 percent in the years $1993 / 1994,2003 / 2004$ and 2009/2010 respectively. This is 40.5 and 43.6 percentage points fewer than in 1993/1994. The poverty gap which measures the consumption shortfall relative to the poverty line was estimated at 8.8 percent in 2009/2010 and indicates that on average Namibia has a poverty gap equal to 8.8 percent of the poverty line [3] (NSA, 2012, p 12).

Keywords: Glimpse; Nutritional Status; Namibian Child; Pensioners; Predominantly women; Dwellers; Statistics Agency; Consumption poverty; Accentuates disease; Micronutrient malnutrition; Devastating; Democratic Health Survey; Poverty Alleviation; Ohangwena; Omusati; Oshikoto; Vulnerable region; Disaggregating

\section{Introduction}

Namibia population stood at 2.1 million in 2011 and 2.3 million in 2016 [4] (NHIES, 2015/16) and is now at 2.4 million [4] (NSA, 2016). Urban dwellers constituted 9, 034.34 in 2011 and 1.1 million in 2016 while 1209.643 in 2011 and 1.2 million in 2016 live in rural areas making the majority of the population (67\%) rural. The population of Namibia is young, with 40 percent under the age of 15; and diverse, with over 10 ethnic groups [5] (NPC 2015). The poverty rate was at $28.7 \%$ while $15.8 \%$ of the population live below $\$ 1.25$ per day, but this has increased to $16.9 \%$ in 2014. More than a quarter of the households (27.6\%) are poor and 13.8 per cent are severely poor (IFAD, 2014). The poorest households are those headed by women [6] (IFAD, 2014). In 2009/10, the poor were predominantly women, subsistent farmers and pensioners that live in rural areas [3] (NSA, 2012) making rural dwellers more affected than those in urban centres. The reduction of poverty and inequality remains a national priority. Public spending on health stood at $\mathrm{N} \$ 2.5$ billion which constitutes $9.8 \%$ of the total public spending.

\section{Methodology}

The researcher used a qualitative research method of text analysis which is defined as decoding the words and images from documents to draw inferences from them. The aim of this research method is to identify important characteristics derived from the texts and images for it to be easily understood. This method of research is important as it provides a baseline information in understanding the overall nature, situation, trends of the problem under investigation.

\section{Discussion}

The Namibia Statistics Agency defines poverty as consumption poverty. The World Health Organisation defines health as a state of complete physical, mental and social wellbeing not merely the absence of diseases and infirmity. This definition accentuates disease prevention as a corner stone for healthful living. Nutrition is interdisciplinary science which is defined as the study of foods, their nutrients and other chemical constituencies and the effects of food constituents on health. Its principles are that food, which provides energy, nutrients and other substances needed for growth and health, is a basic need for humans.

A total of $28 \%$ of the Namibian children were found to be stunted and almost $9 \%$ of the children in the survey were wasted and $26 \%$ were underweight. Children in the north-eastern region experienced the highest rates of underweight and stunting, while wasting was most prevalent in the Central region. The country can only produce $50 \%$ of its cereal needs and the rest is imported from neighboring South Africa [4] (NSA, 2016). This scenario makes the Namibian child susceptible to malnutrition. The Ministry of Health and Social Services acknowledges an increase by $6 \%$ in low birth weight between the years 2000 and 2006 (from 8\% to 14\%). Statistics shows that while the percentage of the underweight children has slightly declined, stunting levels and wasting has 
increased from 27.5 percent to 29 percent from 1992 to 2006. This translates to 1 out of 3 children under five years stunted. This shows that the country "has twice the percentage of moderately stunted children and three times the percentage of severely stunted children than what is expected for a country with its level of economic development." [7] (MHSS, 2013). Due to recurrent drought and many other contributing factors, the Namibia population is facing challenges of micronutrient malnutrition (hidden hunger). Micronutrient malnutrition has a devastating effect and often leads to chronic malnutrition (stunting) and is commonly found in pre-school children, who according to the Ministry of Health and Social Services, is the group that is most affected by anemia. The WHO places Namibia's anemic health problem in the moderate category (20\%), but nonetheless still calls for efforts by the Namibia government to reduce it to normalcy.

The country is also facing another challenge of maternal nutrition which has a negative impact on stunting prevalence in the Namibian children born to underweight mothers. The Namibia Democratic Health Survey (2007) describes the situation as alarming as it falls under very high category of WHO guidelines [8] A total of $15 \%$ of Namibian mothers are underweight. The situation is even more alarming in rural Namibia. It is estimated that $15 \%$ of Namibian mothers are underweight and $60 \%$ are of normal weight (MHSS, 2006). The scenario painted above places nutrition squarely at the centre of the country's development agenda. Following the country's presidential elections of 2014, a new ministry, The Ministry of Poverty Alleviation, was created to address some of these challenges. In addition, Namibia has a Poverty Reduction Strategy, a policy document through which government commits itself to tackle malnutrition. There is an acknowledgement of this challenge by the government. Malnutrition is also identified in the United Nations Development Assistance Framework (UNDAF) as a national challenge for Namibia. The goal of Namibia's Vison 2030 is to have "healthy and food secure nation in which all preventable, infectious and parasitical diseases are under secure control and in which people enjoy a high standard of living with access to quality education, health and other vital services in an atmosphere of sustainable population growth and development." (Vision 20/30, 2004) [9].

The Namibia Child Survival Strategy (2014) gives a glimpse of hope as it shows a decline in the Under Five Mortality Rate (U5MR) from 69 per 1000 births to 55 per 1000 births. Although this is showing a declining trend, it however still shows prevalence of treatable childhood conditions such as malnutrition. Namibia's GNP per capita stands at US\$ 1980 (N\$15840). Although the country is classified as a lower middle-income country, however, there exist a high level of income inequality. In 1993 the share of consumption of the poorest $10 \%$ of the population was $0.5 \%$. In contrast the share of the richest $10 \%$ was about $64.5 \%$ : about 129 times greater than that of the poorest income/consumption decile (UNDP, 2004). Since 1994 GDP per capita at constant prices registered an average growth rate of $1.1 \%$ (NPC, 2003c).
The difference between the country's GDP per capita rank and rank in HDI is -48 , implying inefficiency in the country's performance in translating resources into welfare. The HDI has declined from 0.667 in 1995 to 0.607 in 2002. To address the major challenges of the economy, namely poverty and inequality, the government has put in place various policies, plans and strategies such as the Poverty Reduction Strategy, the National Poverty Reduction Action Programme (NPRAP) 2001-2005 and the National Development Plans and Vision 2030. The country still retains social and economic inequalities inherited from apartheid, and inequality in income distribution is among the highest in the world. Almost one-third of the population (28 percent) lives in poverty and the situation is worsened as a result of the crippling HIV/AIDS epidemic standing at 17\% (UNDP, 2017). Yet the country is regarded one of the wealthiest in Africa, with a per capita GDP in 2004 of $\mathrm{N} \$ 10,400$, due largely to its mining industry (NPC 2006).

The poorest of the population are the Khoisan with the annual average adjusted per capita income of 3,263 compared to the Germans who occupy the highest annual average adjusted per capita income of 87,649 (NDI:2007:16). The global comparative standing of Namibia's Human Development Index (HDI), equates the Germans' standard of living to that of the Swedish and Canadians; the Afrikaans speaking Namibians to that of the Thai's and Albanians (NDI:2007:20).

Namibia imports most of its basic necessities from South Africa which over time has created a dependency syndrome even on items such as foodstuff which the country could internally supply. Agriculture contributes 5\% to the national GDP, while 70\% of the country's population directly obtain their livelihoods from agriculture. Forty three percent (43\%) of the country's population occupy $7 \%$ of the land area of the country in the heavily populated northern regions of Ohangwena, Omusati, Oshana and Oshikoto. In a FAO/WFP report in 2009, overall crop production was estimated to be 139,000 tons. While this is $25 \%$ more than the previous year, Namibia still needed to import 150,000 metric tons of grain to meet market demands for the 2009-2010 marketing year. The most vulnerable regions of the country are in the north and north eastern regions of Namibia. A total of 121891 agricultural households experienced food shortages. The regions of Kavango East (92.0\%), Kavango West (89.2\%) and Kunene (85.4\%) are found to be more vulnerable to food shortages than other regions. //Karas (20.6\%) is the least vulnerable region.

It is estimated that about $80 \%$ of the population lives within $10 \mathrm{~km}$ of public health facilities. In contrast, the findings of the NDHS 2000 indicate that about $70 \%$ of households live within $20 \mathrm{~km}$ of a government health facility. This implies that about 1.2 million (67\%) of Namibian people live within $20 \mathrm{~km}$ of a public health facility. There is a wide inter-regional variation that typifies the duality of Namibian society. Reference to two regions of the country clearly illustrates this fact: in Khomas (a region where the capital city is located), a doctor serves about 2000 people, whereas there are more than 16000 people per doctor in the 
Ohangwena and Omaheke regions. The same trend holds true for the other health resources such as nurses and health facility beds. An average per capita visit to a health facility of 1.7 was registered for the period 2002/03 (MoHSS, 2003). Although this might look favourable when compared to those of most African countries, it falls short of the ideal 2.5 visits per capita that is often recommended for developing countries. It also should be noted that these average figures conceal a lot of useful information that is needed to evaluate existing health policies and plans in terms of their equity implications. Disaggregating by measures of socioeconomic status may give a better and more informative picture.

In Namibia, $15.4 \%$ of girls have their babies before their 20th birthday. In rural areas, this is as high as $17.9 \%$ and in the urban areas, $11.8 \%$ of teenage girls fall pregnant per year. Kavango has the highest prevalence of teen pregnancies at 34\% (WHO, 2009). Notably, Kavango also accounts for the highest stunting prevalence among children under the age of five, further illustrating how early age pregnancies significantly contribute to the inter-generational cycle of under-nutrition and poverty. Women's education has shown to contribute up to $43 \%$ in the reduction of underweight in young children and women's status contributes up to $12 \%$. Combined, empowering women in society can contribute up to $55 \%$ reduction in childhood undernutrition, which outweighs food availability and health and environmental factors.

\section{Conclusion}

Namibia got its independence on 21 March 1990 and since then, the country has been politically stable. Yet, the country faces immense social challenges such as a high rate of unemployment, poverty, Human Immune-deficiency Virus (HIV) and Acquired Immune Deficiency Syndrome (AIDS), and a distribution of income that is among the world's most unequal as only a small percentage of the population lives in conditions expected in an upper middle-income country. The incidence of poor and severely poor individuals in Namibia are currently estimated at 28.7 and 15.3 percent, respectively. The poverty gap was estimated at 8.8 percent in 2009/2010 and indicates that on average Namibia has a poverty gap equal to 8.8 percent of the poverty line. The poor are primarily women, subsistence farmers and pensioners and these groups are disproportionately located in rural areas.

\section{References}

1. Namibia Statistics Agency (2016) Namibia Inter-censal Demographic Survey 2016 Report.

2. UNDP (2018) Human Development Indices and Indicators: Briefing note for countries on the 2018 Statistical Update. Windhoek, Namibia.

3. Namibia Statistics Agency (2012) Namibia Inter-censal Demographic

4. Namibia statistics agency (2016) Namibia household income and expenditure survey (NHIES) 2015/2016: Key poverty indicators (preliminary figures). Windhoek, Namibia, Government of the Republic of Namibia.

5. National Planning Commission (2015) National Planning Commission 2014/2015 Annual Report. Windhoek, Namibia. Government of the Republic of Namibia.

6. IFAD (2014) Republic of Namibia Northern Regions Livestock Development Project Interim Evaluation Report. Namibia,

7. MHSS (2013) Namibia Demographic and Health Survey 2013 Windhoek, Namibia. Government of the Republic of Namibia.

8. WHO (2007) Mental health: strengthening our response.

9. Office of the President (2004) Namibia Vision 2030 Policy Framework for Long-Term National Development. Windhoek, Namibia, Government of the Republic of Namibia.

10. WFP (2017) Namibia Annual Country Report 2017 Country Strategic Plan July 2017-2022.World Food Programme Namibia.

\section{Your next submission with Juniper Publishers} will reach you the below assets

- Quality Editorial service

- Swift Peer Review

- Reprints availability

- E-prints Service

- Manuscript Podcast for convenient understanding

- Global attainment for your research

- Manuscript accessibility in different formats

( Pdf, E-pub, Full Text, Audio)

- Unceasing customer service

Track the below URL for one-step submission https://juniperpublishers.com/online-submission.php 